\title{
Toward the Theory of Urban Spatial Articulation (Study Results at two Commercial Centers in Makassar City, Indonesia)
}

\author{
Tommy S.S. Eisenring \\ Study Program of Urban and Regional Planning \\ Graduate Program, Bosowa University \\ Makassar, Indonesia
}

\begin{abstract}
This article aimed at introduce and offer a thought to the direction establishment of the theory of Urban Spatial Articulation developed and based on the theory of Articulation of Mode of Production-a theory in the realm of macro sociology that offers an assumption that social formations in "periphery" are controlled, at least, by the articulation of two modes of production, i.e capitalist mode of production and pre-capitalist mode of production in which one dominates the other. To understand this theory well, at the beginning of the discussion it is described some significant concepts, then a description of the result of two studies on urban spatial articulation in two urban commercial areas, each of which has the different physical character. The first was a study of urban spatial articulation that occur at a shopping street. While the second, is a study of urban spatial articulation formed in a wholesale market area, where both are located in Makassar City. Both used the theory of articulation of urban spatial as a theoretical foothold, which was collaborated with Lefebvre's theoretical concepts of production and reproduction of space that expected could support the establishment of the theory of Urban Spatial Articulation.
\end{abstract}

Keywords:- Mode of production; Social formation; Force of production; Relation of production.

\section{INTRODUCTION}

Cities in developing countries such as Indonesian cities, have different problems with cities in developed countries. When the capitalist sector developed spaces that become the new centers of urban activity, and ignored the existence of space for the pre-capitalist sector, then what happens was that the penetration and spatial development by the capitalist sector is apparently not necessarily able to dominate fully or eliminate space for the pre-capitalist sector. The need for proximity (in distance) to the centers of industrial activity, trade centers or port areas, then usually the sooner or later at the near or inside the center areas emerged squatter settlements or small business places of the urban poor migrants that looking for additional income in urban areas in which on average lack the necessary skills and education, so they can not take a part in the city\&\#39; s formal sector such as at state or private enterprises and at government bureaucracies in the cities. As a result, these migrants are forced to work in the Informal Sector 1) or low-income workers in the formal sector, and settle in slums, or squatter settlements, and then take little advantage becauseof their proximity to the economic centers of the cities. To understand this phenomenon theoretically, one needs to understand some of the following important concepts.

The term of \&quot;Informal Sector\&quot; since 1970s, has become one of the vocabularies in field of development studies and its definition limitation are still be a subject to debate untill today. In this article, the term is only used to describe a form of urban economic activities in Third World that has different charracters from those of the modern Western economy model, but is not meant to make dichotomy with the \&quot;Formal Sector".

\section{SOCIAL FORMATION AND URBAN SOCIAL FORMATION}

Social Formation is a concept used by Marxist thinkers, most of which are identical to 'community', and refer to the institutional context that provides the conditions of existence of the mode of production. [1]. This concept was created by a Marxist structuralist, Louis Althusser. Althusser used this term as a substitute for the term 'society', because, for Althusser, 'society' is too strongly characterized by, what he regarded as the pre-Marxist humanist conception of social life which is the product of the human individual.

\section{A. The Concept of Social Formation}

Social formation is a Marxist concept referring to the concrete, historical articulation between the capitalist mode of production, persisting pre-capitalist modes of production, and the institutional context of the economy. Social Formation refers to the phenomenon of articulation in a society that uses two or more 'modes of production', in which one of them dominates or tends to dominate the other, sebagaimana diungkapkan oleh Taylor [2], [3], [4]. Thus, the Social Formation can not be separated with the concept of articulation of mode of production, where at least, two different modes of production are coexistent in the asymmetric interrelation pattern [5], [6], [7].

The social formation deals with the dialectic between exploitation and political relationships, between economic and social systems. In one of his postulates, Marx said that: "The totality of these relations of production constitutes the economic structure of society, the real foundation, on which arises a legal and political superstructure and to which correspond definite forms of social consciousness" [8]. In other words, for Marx, the political and legal superstructures arising from the existence of society is nothing but an adjustment to the economic structure of the society formed by the totality of their production relations. 


\section{B. Social Formation in the Third World}

The concept of social formation refers to society (social structure at any level, such as: nation, city, business, university, even family) with all its complexity, since it is historically shaped. It encompasses all the internal contradictions that exist in society, all the emerging and disappearing trends in the economy and the superstructure, in the social relations that encompass all these. In the Third World, capitalists mode of production tends to dominate precapitalists mode of production. When the capitalists, with using their mode of production, break through local societies who still use their own mode of production. The capitalists were faced with resistance by traditional communities, which at the time, had been familiar using their own mode of production i.e pre-capitalists mode of production. [2]; [3]; [9]; [10].

The relationship between the mode of capitalist production, social formation, and social change is interpreted only deterministically and dialectically by the theoretical thought of Marx and Engels. For Cohen [11]; [12], Marx and Engels here have reduced their view of technological and economic determinism, instead Cohen developed his thinking by ignoring the dialectical nature of Marx and Engels' thought. Basically Marxist concepts are material and social, for example, the machine itself is a device that becomes a production tool or production force that produces a production process in the context of a relation. However, for Cohen, the force of production even always as takes place in the context of political struggle. Cohen, on the other hand, attributes it to force of productive that acts as a major determinant in historical change, and he radically divides social (eg, production relations) from matter or extrasocial (ie nature, human, forces of production). Dialectical materialism and dialectical determinism, according to Cohen, inevitably have to rely on the source of the transhistorical change. The historical change here is the effect of a change in the power of production, which, without being dialectical, is understood solely merely as a usual technological change.

\section{Social Formation in the Third World Urban Society}

Before moving on to the discussion on urban social formation in Third World cities, it seems necessary to review the view of Hans-Dieter Evers (born 1935 in Dröbischau)professor in the field of Development Planning studies at Bielefeld University - that the city was not at all a center for modernization renewal or social change. This is demonstrated by in-depth studies on the inherent structure of cities in undeveloped societies. [12]; [13]. Evers also pointed to the theory of "dualism" constructed by Terry McGee [14], which mentions the two different economy sector. The first is the economy sectors dominated by economy of "firm type", and the other is dominated by economy of "bazaar type". The firm type, according to McGee, [14], develops dynamically, while the bazaar type tends to decline. The bazaar type that filled by the migrants from rural areas who lives and operates with "semi-villages" life style in the cities.

Actually, both Evers and McGee, have serious drawbacks, especially in answering why the economy type of bazaar has never been integrated with the economy type of "firm". This question has been answered by Marxists. According to the Marxists, the key lies in the coexistence of the two different modes of production. The increasing urbanization significantly in the cities of the Third World, in line with the rise of capitalist penetration. In this case, capitalist penetration, which is part of the dependency mechanism of the Third World to the First World, has made The Third World prime cities as accumulation centers. This is the main cause of the increasing migration from rural area to urban area. [15]; [16]; [17].

Some other Marxist researchers who focused on mobility studies, such as Forbes [17]; [18]; [19]; [20]; [21]; [22], Setiono [23]; [24]; Eisenring [25], and Hasanuddin [26], further distinguishes permanent and circular migration. Their studies results indicate that circular migration became dominant in Third World cities, when the hope the emergence the disarticulation in rural areas was not immediately fulfilled. As a result, the majority of rural residents rely on two sides, villages and cities. However, the articulation of the mode of production in the "accumulation centers" - in the prime cities caused these circular migrants had never be successful in earning sufficient income even in urban sides. [27]; [28]. For those researchers, this is what causes urban poverty in Third World cities.

In the early 1970s in Indonesia, the process of crisis began to be faced by the small enterprices, where they were forced to face the articulation of large producers with the commencement of capitalist penetration in cities. As a result, there began to be a shift in the value of large-scale production in "unbalanced exchanges". In this process, the profits of small entrepreneurs fall below the minimum wage rate which based on the cost of reproduction of labor, by the capitalist sector. Since then, social formation has begun to be dominated by the capitalist mode of production. Why did the crisis not happen before the 1970s?. In the late 1950s and early 1960s, Soekarno - the first president of Indonesian - created some erratically economic policies, to weaken the position of the capitalist sector on the one hand, and on the other side, the small-scale commodity sector was given the opportunity to develop their scale of production be bigger. Therefore, according to Forbes, the small-scale commodity sector was given the opportunities to develop their scale of production to be bigger. Therefore, according to Forbes, the small scale business of small producers is not a permanent feature, but is the result of a certain articulation process at a particular point in time. [7]. [18].

\section{FORCES OF PRODUCTION AND RELATIONS OF PRODUCTION OF URBAN SOCIAL ENTITIES.}

To understand how forces of production and relations of production work in urban social entities, we need to understand the concept of the mode of production that is part of the mode of life.

\section{A. Mode of Life and Mode of Production}

The mode of life is the material and cultural environment in which people meet their needs for life (whether for health, food, housing or necessities such as education, science, 
parenting, etc.). How to satisfy the needs of a society depends on the mode of production, in addition to the customs, habits, national traditions of the society. [29].

Production begins by developing its decisive aspectthe forces of production-which once they reach a certain level, they enter into conflict with relations of production. where they have grown. This led to an inevitable change in relations of production. Therefore, a change in the mode of production is not only aroused by the will of the people, but also by the correspondence between a productive relationship with the character and level of development of forces of productive.. [29].

Having understood the concept of the mode of production and how the forces of production as well as relations of production, work in it, the following discussion deals with the concepts on forces and relations of production, and how they work in different modes of production. The theorists of Articulation of Mode of Production such as Meillasoux [30], Terray [31], Rey [32]; [33], and Taylor [2]; [3], then concentrated their studies on the articulations in Third World societies, and showed the coexistence between at least two modes of production - capitalist mode of production and the pre-capitalist mode of production. In the following discussion it is described how the forces and relations of production operate in both modes of production

\section{B. Forces of Production and Relations of Production}

Marx believed that the basis of social order in every society is the production of economic goods. What is produced, how to produce it, and how it is exchanged, determines the number of people, power, and social status of a society.

Forces of Production include manpower, workers and means of production, such as equipment, buildings, technology, and knowledge, materials, as well as mature soils). in essence, the forces of production, is the technology and work patterns that people use to exploit their environment to meet their needs. While Relation of Production is a concept often used by Marx and Engels in their theory of Historical Materialism, and in their work, Das Kapital. [34]; [35]; [36]. Marx defined relations of production as the social relations of the people who enter into the relationship by their participation in economic life.

\section{Modes of Production and Urban Social Entities}

'Modes of production' is often defined as a specific combination of the forces of production and the relations of production. And that the character of relations of production is a determining factor that distinguishes one type and another from the mode of production in society.

To facilitate discussion in this section, the social entities are divided into two social entities-capitalistic social entity and pre-capitalistic social entity. The capitalistic entity that is meant here is a group of urban communities that relate and rely on their lives on the capitalistic system. While precapitalistic entity are intended as a society group that has no direct connection with the capitalistic system and does not rely their lives on the capitalistic system. Economic elites, political elites, state officials, government officials, civil servants and members of the Police and Armed Forces, authorized entrepreneurs, professionals, private employees, including factory workers, licensed taxi drivers and other subjects urban areas that integrate their lives with the formal system-the capitalistic system-can be called the 'capitalistic social entity'. They base their lives on capitalist mode of production, which includes all formal systems, such as payroll systems, state economic and political systems, banking systems, formal education systems, any legal and regulatory systems, any spatial and building codes applicable in urban areas, both locally and nationally, etc.

While the trishaw riders, street vendors, small traveling merchants, illegal parking attendants, street singers, and other workers in the informal economy that exist in urban areas, can be categorized here as 'non-capitalistic social entity'. In urban areas of Indonesia, this entity is generally characterized by their own distinctive features, such as: not having a place of business license or for an individual services business; do not rely on college diplomas; relatively small working capital, very simple business management; work individually or with the number of workers only a few people which are recruited on the basis of kinship or by their own family; The business is run without the need for formal education or special skills, but only by experience; the technology used is very simple, less organized; hours of less regular activities; the type of business that is employed is usually in the form of trade craftsmen and services, or labor on a part-time basis and in binding works, it rarely uses written employment contracts; less have a habit of saving or borrowing money from institutions such as cooperatives and banks; and their production is usually only for people in their own entity or for some of the lower middle segment. [14]; [3]

While the trishaw riders, street vendors, traveling small traders, illegal parking attendants, street singers, and other workers in the informal economy that exist in urban areas, can be categorized here as 'non-capitalistic social entity'. In urban areas of Indonesia, this entity is generally characterized by their own distinctive features, such as: not having a place of business license or for an individual services business; do not rely on college diplomas; relatively small working capital, very simple business management; work individually or with the number of workers only a few people which are recruited on the basis of kinship or by their own family; The business is run without the need for formal education or special skills, but only by experience; the technology used is very simple, less organized; hours of less regular activity; the type of business that is employed is usually in the form of trade craftsmen and services, or labor on a part-time basis and in binding work rarely uses written employment contracts; less have a habit of saving or borrowing money in institutions such as cooperatives and banks; and their production is usually only for people in their own entity or for some of the lower middle segment. [14]; [37]; [38]. .

\section{Forces and Relations of Production of the Capitalistic Urban Social Entity}

The forces of production for capitalistic social urban entity, as in other forces of production, includes manpowers, laborers and means of production. The means of production for capitalistic entity may include everything, both an abstract things such as urban regulations (urban spatial and detailed spatial regulation, building codes, building permits, and local zoning regulations, etc.), management, banking, formal education systems, and as concrete things such as land and 
building controls, vehicles, and machinery. Urban regulations give powers to this entity, especially to master the most productive resources in urban areas. The adherents of Critical Urban Theory emphasize that the conditions of cities today are politically and ideologically are mediated, while socially contested, and hence city conditions forge the character of urban space-that is, the continuous reconstruction of places, media and outcomes of relations historically specific of social forces. [39]. The urbanists within this entity use political power and capital as their means of mediation in the struggle the potential sources in urban areas. Economiclly potential lands, better employment opportunities, better schools, and other forms of facilities and facilities sufficient for their living. The capitalist mode of production helps the people within this urban capitalistic social entity produce their lives with profitable production relations.

Relationships with banks, for example, help them to acquire venture capital in developing their business. The education system, especially the higher education system, allows people to be used and utilize their energy or skills they possess, in order that they can produce and reproduce their lives. Earnings gained in any formal institution may give them the possibility of having their relations of production with real estate developers, for example, to acquire potential lands as a place of business, or as a decent and comfortable dwelling. The existence of pre-capitalist urban social entity is also as a force and relation of production for the capitalistic urban social entity-especially the urban middle-class economypeople, to gain an advantage in the form of family financial savings due to the availability of very cheap goods and services offered, for example, the trishaw riders, trishaw riders, street vendors, traveling traders, as well as traditional economic facilities, such as traditional markets, temporary markets, street markets, food stalls and so forth provide economy benefit for people of middle-class of the users of capitalist urban social entity.

From the discussion of the forces of production and relations of production between two different users of modes of production - urban capitalistic social entity and urban precapitalistic social entity - it is seen that in the coexistence of the both modes of production, i.e the capitalist mode of production and the pre-capitalist mode of production, then capitalist mode of production tends to dominate non-capitalist mode of production. However, there is an intertwined among the different urban entities on the different modes of production.

When capitalists with their mode of production break through the urban local society that still using pre-capitalist mode of production, a part of urbanists had integrated themselves into capitalistic social formations, especially those who have higher education or have the capital for a formal enterprise, and some other-the pre-capitalist societyinsisted on pre-capitalistic mode of production, and untill today reject the capitalist mode of production [2]; [3]; [4]; [9]; [10]. According to Taylor [10], both the reproductive needs and the resistance needs, both are constantly changing over time. What Andriani [40] and Idris [41] had found in their studies in Makassar shows that the middle economic group that has already integrated with the capitalist mode of production, in fact still maintains their production relations with pre-capitalist urban social entity. On the contrary, those within pre-capitalist social entity-trishaw riders, peddlers, traders in traditional markets, and so on-also still maintain their relations of production with their customers from capitalist urban social entity - i.e with the middle-class circles.

\section{URBAN SPACE MASTERY AS A MODE OF PRODUCTION}

One of the important forces of production for urban societies, whether those within the capitalistic social entity, or those in the non-capitalistic social entity, is the control of the potential land. By using their own mode of production, each social entity competes to master the most productive lands. Capitalistic social entity use capitalist mode of productionwhich includes legal systems and legislation relating to formal land tenure and property ownership, urban land-use system, urban zoning regulations, governance of the building system, and any form of formal system - to support their efforts in mastering the productive lands, adequate and comfortable dwellings in the best locations in urban areas, with a sense of security in formal ways.

While non-capitalist social entity inhabit squatter settlement and slums or small spaces with very cheap rents, however, the spaces are adjacent to the centers of urban economic activities - or other urban facility centers - which allowing them to access employment and just get earns very bit there.

\section{A. Lefebvre's Concept on Spatial Triad}

Lefebvre's concept of spatial triad, which includes Spatial Practice, Space Representation and Space Representation, can explain how the two urban social entities control the urban spaces (Fig.1)

Before the capitalists enter the Third World cities, in fact pre-capitalist societies do not yet know what is called 'spatial representation', which relates to the relations of production, and to 'order' in which relationships lead to knowledge, to signs, on the rules, and on the frontal relationship [9].

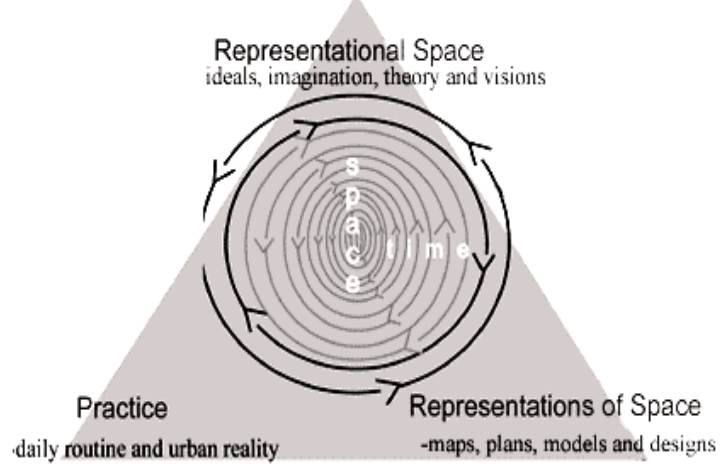

Fig 1:- Anderson's Diagram of Lefebvre's Spatial Triad

(Source: Hannah Anderson, 2007)

Unlike the capitalist mode of production that relies on the reprensentation of space, initially the pre-capitalist society only recognizes the pre-capitalist mode of production, they are only doing spatial practices. Spatial practices are initiated, 
for example, by the desire to approach the productive sources, such as forests to hunt and search for forest result, marine products for traditional fishermen, fields and gardens for traditional farming communities, where they do not recognize the representation of space, as in the capitalist mode of production.

In urban areas they are driven by the desire or need to approach urban economic centers, such as markets, terminals, ports, etc. Such a practice of space then transforms into a temporary spaces and cumulatively becomes the symbolic practice of space. [9]. This practice of space that has been converted into symbolic practice then creates a representative spaces, which is understood as a space directly animated by connected images and symbols as 'occupants' and 'users' spaces. [9]. The space of representation in urban areas arises from the life experience of pre-capitalistic social entity, resulting from the dialectical relationship between the spatial practice of this entity and the representation of space designed and controlled by the capitalistic urban social entity.

That is the cause of the emergence of slums, and squatter settlements around or within any urban centers of formal activities, especially at urban commercial center areas.

\section{B. Concept on 'Dominated Space and Appropriated Space'}

The Lefebvre Concept on Dominated Space and Appropriated Space can explain the urban spatial antagonism, It is not just comparing "natural" spaces with "unnatural ones" but further up to the antagonism between spaces projected by 'power' and spaces organized by 'collective practice'.

In urban areas, spatial antagonism arises from differences between capitalist and pre-capitalist modes of production. The dominated spaces are not only 'artificial' spaces, but also spaces that are deliberately set up to mediate and organize their interests in capitalistic social entities. This social entity is facilitated by abstraction tools such as urban spatial regulation, land use plans, and certificates and permits such as land owner certficate, building construction permits, property licenses, real estate development project licenses, and so on. While appropriated spaces are reproduced by spaces organized i.e.by 'collective practices' of they incorporated in non-capitalistic social entities, where finally they find their own order spontaneously following the contours of movement, and without being facilitated by abstraction devices.

Thus, the Dominated Space and Appropriated Space in urban areas imply the distinction between two types of space under different modes of production. The Dominated Space is a space dominated by capitalistic urban social entity. While the adjusted space is dominated by non-capitalistic urban social entity.

\section{The Concept on 'Abstract Space, Differential Space, and Social Space'.}

In his book, The Production of Space, (1991) Lefebvre explained the different concepts of Abstract Space, Differential Space, and Social Space.

Abstract Space is a space created by capitalism and neocapitalism, which includes the world of commodities, with its logics and global strategies, as well as the power of money and the political power of the state. Abstract space is not limited to 'dominated spaces', but can include such vast networks as financial institutions and banks, business centers, major productive business entities, including fast lanes, air ports and even the information grid. By the abstract space, capitalism creates homogenization, hierarchization, and social fragmentation. The spread of global capitalization through abstract space has resulted in more similarities than differences. Shopping malls, in almost all cities around the World, show more similarities than their differences, aiming at creating visual famialiarity by the creating the visual visibility and space atmosphere. [42]; [43]. The creation of such homogenization, hierarchization and social fragmentation is also evident in other means of consumption, such as minimarkets, hypermarkets, trade centers, apartments, wholesale markets, centers and amusement parks, real estate settlements (luxurious to modest), hotels, and so forth.

\section{THE RESULTS OF STUDIES AT TWO COMMERCIAL CENTERS IN MAKASSAR CITY}

The two studies that were conducted at two urban commercial center areas in Makassar City-where the authors were involved as a supervisor in both studies-were studies that could be seen as an approaches toward the emergence Theory of Articulation of Urban Spatial. The first is a study that was conducted by Linggar I. Eisenring (2015) at the locality of "Somba Opu" street shopping center [44], and the secondly, a study that was conducted by Muhammad Nawir (2016) at "Daya" Wholesale Market area. Both studies took directly the basic principles of urban spatial articulation as their footing in constructing their research propositions.

\section{A. The Study at the Locality of "Somba Opu" Street Shopping Center in Makassar City}

The results of a study conducted by L. I .. Eisenring in 2015 indicated that the spatial pattern on the locality of Somba Opu street shopping center composed of the Capitalist Space and Non-Capitalist Space. The Capitalist Space, in this case, was the space of the "Somba Opu" Street Shopping Center, located at left and right the street, entirely are permanent buildings, has existed and occupied by the shopowners legally long before the independence of Indonesia. While the PreCapitalist space was inhabited by the Somba Opu "original" community, and by the tenants of out-of-home job seekers who took advantage of the proximity to their workplaces at "Somba Opu" street shopping center. [44]

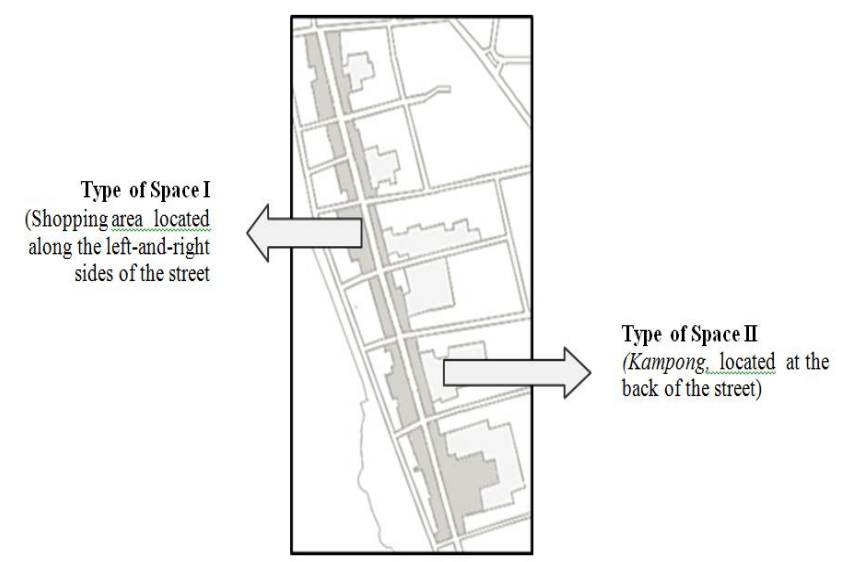

Fig 2:- Locality Map of "Somba Opu" Street Shopping Center, with 2 (two) types of Space: Capitalist 
Space and Pre-Capitalist Space

(Source: L. I. Eisenring, 2016)

The presence of capitalist and non/ pre-capitalist space mastery (Fig. 2) shows there was a coexistence between the two different modes of production socially at the locality. L. I. Eisenring showed that there was a harmonious condition between the two users of space. the users of capitalist space often contribute at the public interest of "indigenues" communities, who live behind their stores, while the "indigenues" communities provide security guarantees for shopkeepers so they can freely operate their business. This condition, for L.I. Eisenring. is as a complementary coexistence of a social formation.

In addition, L. I. Eisenring (2015) also discovered the type of small spaces that usualy be used for small businesses on "sidewalks" along Somba Opu street, precisely for the activities of gold craftsmen. The rights to use these small spaces was organized and managed illegally by influential figures among the "original" community members.

\section{B. The Study at "Daya" Wholesale Market Area in Makassar City}

The other study, is what Nawir (2016) conducted on his research at "Daya" Wholesale Market Area in Makassar. The study core is a empirical description about a spatial articulation occurring at a center of urban commercial activities in this city. This area is located in the northeastern part of Makassar City, a new area of commercial activities center in the city. Under the plan by the developer, this area consists of several blocks of wholesale centers surrounded by shops; and a modern traditional market.

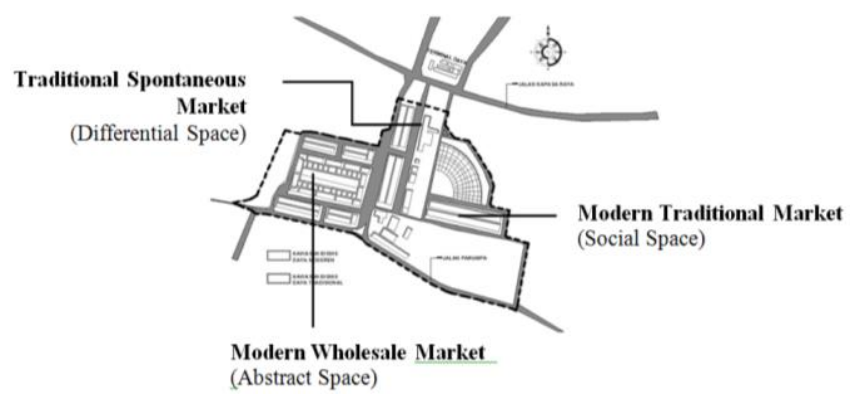

Fig 3:- The Map of "Daya" Wholesale Market Area in Makassar City

(Source: Nawir, 2016)

At the time of this study, the physical construction of dominated spaces in the region was almost fully awakened. One of the Nawir's study results shows that spatial articulation has manifested within the commercial area. Apart from the spaces dominated by the wholesale markets and shops referred to as abstract spaces (as conceptualized by Lefebvre), and social space in the form of traditional modern markets, there are also deferential spaces that are appropriately evolved at the edges of one of the road spaces that is in the area. ( Fig. 3). One of Nawir's significant postulate is that Social Space, in the form of "modern traditional markets" which was reproduced in the area for the purpose of controlling traditional economic actors activities in this area, in fact, is insufficiently effective in avoiding the emerged the articulation of spatial within this commercial area. This spatial articulation here was manifested by the emergence of a Differential Space at one of the streets in the commercial area that is filled with traditional street small traders. [45]

\section{CONCLUSION}

The concepts that have been described at the initial part of this article, and also the results of the two studies conducted in Makassar City, have led us toward the formation of the theory of Ariculation of Urban Spatial - a spatial theory which much be influenced by Marxist theories, especially the theory of Articulation of Mode of Production as well as Lefebvre's concepts of production of space. Urban spatial Articultion lays the groundworks on the coexistence of two forms of urban space mastery. According to me, it implies at least 2 (two) propositions. The first is the assumption that there are, at least, two types of urban land or space mastery, where the most visible is domination of legal land mastery by the capitalist sector, while the illegal occupation is dominated by the pre-capitalist sector. In their coexistence, the dominated space by the capitalist sector has a greater chance in the process of production and accumulation. The second is an assumption that when the capitalist sector reproduces space at an urban area or a suburban area, the sooner or later, precapitalist sector will also articulate it by the way of reproducing illegal or semi-illegal spaces within or around the space which have been reproduced by that capitalist sector.

\section{REFERENCES}

[1] T.S.S. Eisenring-Concepts and Theories of Urban Sociology. Makassar: Fahmis Pustaka. 2017

[2] J. Taylor-Precapitalism modes of production. Critique in Anthropology, 4, 5: 1975. pp. 127-55.

[3] J. Taylor-Precapitalism modes of production (Part 2)". Critique in Anthropology, 6, 2: 1976. Pp 56-69

[4] J. Taylor-From Modernization to Modes of Production. London: Macmllan.1979

[5] P. Badruii-Imperislism and Ethnic in Nigeria 19601996. Trenton: Africa World Press, Inc. 1998

[6] B. Surya-Social Change at Local Community of Tanjung Bunga Area of Makassar City, PhD Desertation. Study Program of Sociology. Postgraduate Program, Makassar State University. 2010

[7] B. Surya-The processes analysis of urbanization, spatial articulation, social change and social capital difference in the dynamics of new town development in the fringe area of Makassar City (case study: In Metro Tanjung Bunga Area,Makassar City). Procedia - Social and Behavioral Sciences. 227. 2016. Pp 216-31

[8] K. Marx-A Contribution to the Critique of Political Economy. New York: International Publishers. $1859 / 1970$

[9] H. Lefebvre-The Production of Space, (Original title: La Produktion de L'espace, translated to English by Donald Nicholson-Smith). Malden: Blackwell. 1979/1991. 
[10] H. Lefebvre-Writing on Cities. New York: Blacwell Publisher. 1996

[11] D. J. Cohen - The Political Situation of Low-Income Communities in Jakarta. Prisma No. 7, 1972. pp 54-64

[12] H. D. Evers-Subsistent Production of Floating Mass of Jakarta. Prisma No. 7, 1972. pp 35-43

[13] H. D. Evers-Urban Sociology: Urbanization and Land Disputes in Indonesia and Malaysia. Jakarta: Penerbit LP3ES, 1972.

[14] T.M. McGee-Structural and City Changes in the Third World: A City Involution Theory, in Urbanization, Unemployment and the Informal Sector in the City, C. Manning and T.N. Effendy (eds). Jakarta PT. Gramedia. 1985. pp 34-59

[15] L.R. Bromley-Organization, Arrangement and Entrepreneurship of the Informal Sector in the City: Street Traders in Colombia", in Urbanization, Unemployment and the Informal Sector in the City, C. Manning, C. and T.N. Effendy (eds). Jakarta: PT. Gramedia. 1998: 228-50

[16] A. S. Dwiyanto- Evaluation of Poverty Alleviation Policy During PJP I, in Poverty and Gaps in Indonesia, A.S. Dewanta, (ed). Jakarta: Aditya Media. 1995: 65-74

[17] I. Roxborough-Theories of Underdevelepment (translation). Jakarta: LP3ES. 1990

[18] D. K. Forbes-Development and the "Informal Sector". A Study of Paddlars and Trishaw Riders in Ujung Pandang, Indonesia. PhD Disertation, the Autralia National University, 1979

[19] D.K. Forbes-Mobility and Unever Development of Explanations of Migration and Circular Migration", in, Population Mobility and Development: Southest Asia and Pacific, G.W Jones and H.V. Riche (eds), Canberra: The Australia National University. 1981, pp 51-70

[20] D. K. Forbes-Population Mobility in Indonesia Revisited. Prisma The Indonesian Indicator, No. 20 March: 1981. pp 69-77.

[21] D.K. Forbes - The Vendors in Ujung Pandang, in Urbanization, Unemployment, and the Informal Sector in the City. C. Manning and T.N. Effendy (eds) Jakarta: PT. Gramedia. 1985:347-77

[22] D.K. Forbes-Geography of Underdevelopment: A Critical Survey. Jakarta: LP3ES. 1986

[23] H. Setiono-Urban Small-Scale Enterprise and Development: A Study of Unregistred Building Construction Sector in Ujung Pandang. PhD Disertation. Departement of Urban and Regional Planning, University of Sydney, 1992

[24] H. Setiono-Rural-Urban Circular Migration and Development: The Case of Building Construstion Labourers in Ujung Pandang, Indonesia. Master Thesis. Departement of Urban and Regional Planning. University of Sydney, 1993.

[25] T.S.S. Eisenring-Rural-Urban Circular Migration: Study of Trishaw Riders based at the Street of Rappocini Raya in Ujung Pandang. Master Thesis. Study Program of Urban Management, Postgraduate Program, Hasanuddin University, Makassar, 1996.
[26] S. Hasanuddin, S.-Urban-Rural Commuter Migration: Study of the Small Trader Cycling Commuters in Ujung Pandang. Master Thesis. Study Program of Urban Management, Postgraduate Program, Hasanuddin University, Makassar, 1996.

[27] J.P. Lea-Self-help and Autonomy in Housing: Theoritical Critics and Empirical Investigators,. in Housing in Third World Contries: Perspective on Policy and Practice, H.S. Muruson, and J.P. Lea (eds) . London: McMillan Press, Ltd. 1979. pp. 3-16.

[28] J. P. Lea and J. M. Courney-Conflict Resolution and Asian City: An Overview", in Housing in Third World Contries: Perspective on Policy and Practice, H.S. Muruson, and J.P. Lea (eds).. London McMillan Press, Ltd 1985. pp. 49-53

[29] Ensiclopedia of Marxixm (February 2016) -Mode of Life; Mode of Production. Enciclopedia of Marxixm: Glosary of Term. Online: (https://www. marxists.org/glossary/terms/m/o.htm\#mode-production).

[30] C. Meillassoux-From Reproduction to Production", Economic and Society 1, 1, 1972. Pp. 93-105.

[31] E. Terray-Marxism and "Primitive" Society. New York: Monthly Review Press. 1972

[32] P. P. Rey-The Lineage Mode of Production". Critique of Antropology, 3. 1975, pp 27-60

[33] P. P. Rey-Class, Contradiction in Lineage Societies". Critique of Antropology . 4.13/14. 1979. pp 41-60

[34] K. Marx, K. and F. Engels-Poverty of Philosophy (translated from "Misere De La Philosophie" by: H. Quclec). Chicago: Kerr \& Company. 1848.

[35] Marx, K., (1867). Das Kapital. Volume I (Capital). (S. Moore and E. Aveling, Translaters.) Public Domain Books, Kindle Edition (2008-11-19). 1867

[36] K. Marx-Capital: Volume III. (D. Fernbach, Translater) New York: Penguin Books. 1894/1991

[37] G. F. Papanek, G.F., and D.K. Jakti, D.K., (1986). "The Poor in Jakarta, in Poverty in Indonesia D.K. Jakti (ed.): Jakarta: Yayasan Obor Indonesia. 1986. pp 86-117

[38] T.S.S. Eienring - Housing and Urban Settlements Based on Sustainable Spatial Articulation (Towards the Ideal Urban Housing and Settlement Concept in Indonesia). Paper presented at the National Seminar on "Looking For The Ideal Concept of Housing and Settlements in Urban". Imperia Aryaduta Hotel, Makassar, Ministery of PUPR. 09 ${ }^{\text {th }}$ Desember 2016.

[39] N. Benner-What is Critical Urban Theory, in City For People Not For Profit and Rights the City. New York and London: Routledge, 2009

[40] E. Andriani.-An analysis of the role of pegandeng (small trader cycling) in Improving Urban Efficiency (Case Study in Two Housing Environments in Makassar City. Undergraduate thesis. Department of Urban and Regional Planning. Alaudin State Islam University, Makassar, 2015.

[41] S. Idris-Urban Efficiency and The Pattern of Supply Chain on Street Traditional Market (A Study at "Terong" Street Market, Makassar). Master Thesis, Study Program of Urban and Regional Planning. 
Postgraduate Program, Bosowa University, Makassar. 2014.

[42] T. S. S. Eisenring-Architecture Social Contruction on Consuptivism: Study at Three Shopping Mall in Makassar. PhD Disertation. Study Program of Sociology. Postgraduate Program, Makassar State University. 2010.

[43] T. S. S. Eisenring - Social Construction (Postmodernism and Consumptivism). Makassar: Fahmis Pustaka, 2014.

[44] L.I. Eisenring - Social Formation and Urban Spatial Articulation (A Study at the Locality of Somba Opu Street Shopping Center in Makassar City. Master Thesis, Study Program of Urban and Regional Planning. Postgraduate Program, Bosowa University, Makassar. 2015

[45] M. Nawir, M., 2016. Urban Space Mastery and Urban Social Coexistence (Case Study of "Daya" Wholesale Market of Makassar). PhD Disertation. Study Program of Sociology. Postgraduate Program, Makassar State University, 2016. 